\begin{tabular}{|l|l|}
\hline & \multicolumn{2}{|c|}{ SNP Best-set Typesetter Ltd. } \\
\hline Journal Code: NTWE & Proofreader: Elsie \\
\hline Article No: 235 & Delivery date: 18 December 2009 \\
\hline Page Extent: 17 & Copyeditor: Mildred \\
\hline
\end{tabular}

New Technology, Work and Employment 25:1

ISSN 0268-1072

\title{
The next available agent: work organisation in Indian call centres
}

\section{Mohan Thite and Bob Russell}

\begin{abstract}
The offshoring of customer contact service work to distant locations such as India has become commonplace in the last few years. Indian call centre/business process outsourcing (BPO) providers employ over half a million young and highly educated customer service agents, offering them job opportunities that were, hitherto, unavailable, yet attrition rates have grown to alarming proportions, threatening the future viability of this new industry. The inherent negative characteristics of offshored call centre work with high-performance monitoring and low job discretion are said to contribute to employee dissatisfaction. In this empirical study of four large Indian call centre/BPO providers, we examined the employee perception of work organisation and found that there was a mismatch between the BPO labour market and the labour process that characterises much of the work. This situation posed fundamental challenges to the BPO model of development that may not be susceptible to easy human resource fixes.
\end{abstract}

\section{Introduction}

Surely, one of the most tangible expressions of the phenomena that falls under the rubric of globalisation is the extension of the technical division of labour to far-flung, overseas locations. These developments entail a different modus operandi to the accumulation of capital than patterns that were formally associated with the interna-

$\square$ Mohan Thite (M.Thitegriffith.edu.au) is a senior lecturer at Griffith Business School, Griffith University, Brisbane, Australia. His research interests include strategic HRM in the knowledge economy, HRM in the Asia Pacific, HRM in multinational corporations from emerging economies and HRM in Indian IT/BPO. Bob Russell (bob.russell@griffith.edu.au) is an associate professor at Griffith Business School, Griffith University, Brisbane, Australia. He has written on industrial relations in Canada and work transformation in the mining industry. Currently, he is conducting research on call centres, information work and globalisation. 
tionalisation of economic activity. Rather than dedicated production for discrete home markets, production and consumption are spatially severed in a world preoccupied with 'competitive advantage' (Beck, 2000; Dicken, 2007; Harvey, 2007). Global supply chains and complex business-to-business relationships displace localised (i.e. national) production regimes and give rise to whole new fields of managerial inquiry and application such as logistics management, principal-agency relations, information management and international (i.e. global) HRM (Boltanski and Chiapello, 2005). First observable within the realm of the production of physical commodities, including textiles and apparel production, auto parts and electronic goods production (Gereffi, 1994), the enactment of certain forms of information and service labour has been subject to the same geo-economic logics of radical dispersal to distant spatial clusters.

Nowhere is this dynamic more obvious than in the advent of business process outsourcing (BPO) of information technology-enabled services (ITES) to the Indian subcontinent. A business process is any work flow that is required to produce an output. In the domain of ITES, the term is applied to the production, distribution or use of information, either on behalf of other businesses or for the clients of such concerns. As such, common examples of BPO include data entry and other types of 'back office' work such as administrative labour as well as over-the-phone customer service work (i.e. call centre work) and telemarketing, which are also undertaken through call centres. It is also the case that more skilled work, including IT/software work, as well as various levels of research and development, is undertaken through this model of work organisation, although these types of activities, often referred to as knowledge process outsourcing (KPO) are not considered in this paper. ITES/BPO work may be undertaken 'in-house', in the overseas' subsidiaries of foreign multinationals that are referred to as 'captive' units or it may be outsourced to third-party service providers such as multinational corporations (MNCs) that set up operations in foreign host economies or MNCs that are domiciled in the country where the work is performed (Srivastava and Theodore, 2006). Owing to the opacity of BPO relations, itself a product of confidential firm-to-firm agreements and spatial distanciation, research on the implications of this form of work is still in an early phase of development. Our objective in this paper is to further explore the implications of this form of globalised work organisation for those who undertake the work.

India has occupied a central place in these recent developments. Over the last several years, it has grown to take on about a quarter of the global offshored BPO market (KPMG, 2004: 12). ${ }^{1}$ The Indian ITES sector earned a revenue of US $\$ 8.4$ billion in 2006-2007 with an annual growth rate of 33.5 per cent (NASSCOM, 2007). The sector now consists of over 400 companies that employ over half a million workers. With an annual graduate supply of about three million and more than half the population below the age of 25, India is said to have the 'largest pool of offshore talent-accounting for 28 per cent of the total suitable pool available across all offshore destinations and outpacing the share of the next closest destination by a factor of $2.5^{\prime}$ (NASSCOM, 2006a). This talent pool composed of a young, well-educated workforce that is fluent in English is a major attraction for the globalised BPO model.,

In spite of what could be regarded as highly favourable conditions for the establishment of BPO operators, skill shortages and employee turnover have quickly become major challenges that face the burgeoning industry (Slater, 2004; Budhwar et al., 2006a,b). A comparative analysis of call centres in the Asia-Pacific region, including China, Korea, India, the Philippines and Singapore, revealed that while India had the second lowest average full-time customer service agent annual salary (US\$3,334) behind China, it had the greatest level of agent attrition (38 per cent), lowest average employee tenure (11 months) and highest average sick days taken per agent per annum (15 days) (Wallace, 2009). Similarly, according to a global call centre study, Indian call centres have the highest employee turnover of 40 per cent against a global average of 20 per cent and almost 60 per cent of employees have less than one year of tenure at work (Holman et al., 2007). It is estimated that there may possibly be a skill shortage of over a quarter of a million workers in the Indian ITES 
industry by 2009 (KPMG, 2004: 19). The problem relates not so much to the quantity of available labour but to its employability and trainability (Taskforce, 2003: 6).

Existing studies of Indian call centres are characterised more by 'heated debate than systematic empirical investigation' (Batt et al., 2005b). Research that has explored employment relations in Indian call centres trace the problems to the inherent nature of the business model adopted by BPO providers that emphasises high levels of routinisation and standardisation, the specific labour processes geared to high levels of performance monitoring and low job discretion and the negative characteristics of the work environment where most of the work is carried out during the so-called graveyard shifts, servicing overseas customers under a masked identity (Ramesh, 2004; Batt et al., 2005a,b; Taylor and Bain, 2006; Budhwar et al., 2006a,b; Mirchandani, 2009). Many of these studies are based upon descriptive evidence (Taylor and Bain, 2005; Budhwar et al., 2006a) or on managerial surveys (Batt et al., 2005a). Presumably, because of the difficulties in gaining access to BPO workforces, employee voices have largely been absent in survey research on Indian call centres with a possible 'top-down' bias. Meanwhile, with few exceptions (Taylor et al., 2009), the existing studies that have attempted to tap into employee perceptions of human resources (HR) in Indian call centres have either relied upon very small samples of customer service representatives (CSRs) (Shah and Band, 2003; D'Cruz and Noronha, 2006) or upon small numbers of workers spread across a larger number of organisations (Budhwar et al., 2006a).

The study we report upon here takes a different approach. We elicit the perceptions of employees on the front lines of BPO customer service at four large Indian ITES providers. This paper addresses the issues and challenges of work organisation in providing customer service from afar through outsourcing, with particular reference to Indian customer contact centres and the $\mathrm{BPO}$ model. We focus on specific aspects of work organisation, namely workload manageability, performance monitoring and job discretion, as perceived by those whom it affects the most: the employees who staff the $\mathrm{BPO}$ operations. We begin by introducing the business models and strategies adopted by call centres, with a particular emphasis on Indian operations. We then present our research methodology and results followed by a discussion of the implications of the result and, their limitations, and identify possibilities for future research directions.

\section{Factors influencing call centre business and work}

According to a global call centre report, 'national labour market institutions influence management strategies' (Holman et al., 2007). It found that in general, call centres in coordinated or social market economies (with strong labour market regulations) tend to have better quality jobs and lower turnover than call centres in liberal market economies (with more relaxed regulations) and in recently industrialised or transitional economies. Further, in analysing the link between business strategy and HR practice, a distinction needs to be made between in-house, outsourced and offshored call centres. Batt et al. (2005b) found that in-house centres in the USA tended to adopt a more coherent quasi-professional approach to service interactions, whereas outsourced and offshore sites in the USA and India, respectively, had significantly lower levels of employee discretion and higher levels of electronic monitoring and performance management. On the other hand, conducting survey research among Indian $\mathrm{BPO}$ union members, Taylor et al. (2009) found little difference in respondents' perceptions of the presence of working issues that are conducive to trade union joining in MNC captive, Indian third party and Indian domestic operations.

In the context of call centres, it has been claimed that there are two main customer segments, one for mass market users with simple, routine needs that are conducive to a cost-minimisation strategy and another for a customised market that promotes innovative, relationship-building strategies (Batt, 2000; 2002). These market segments define the key operational requirements of HRM, such as work design that determines the nature and extent of work discretion and performance monitoring (Taylor and Bain, 2005: 263; Wood et al., 2006). Routine, transactional tasks require low employee discretion and high-performance monitoring as the emphasis is on minimising costs and 
maximising efficiency. On the other hand, complex, relational tasks require employees with high levels of education, functional expertise and discretion. In between the low end mass production model and high-end professional services model, Batt and Moynihan (2002) also proposed a hybrid model that they call mass customisation (also, see Korczynski et al., 2000 and Korczynski, 2001). They suggested that a mass customisation strategy coupled with high-involvement work practices is an economically viable model for service and sales call centres. Kinnie et al. (2000) found evidence for this kind of hybridisation in call centres between elements of commitment and control that are combined in a 'fun and surveillance' complex. Similarly, Houlihan (2002) finds that the paradoxical strategy of 'low discretion, high commitment' operates in call centres in a variety of forms, with a persistent pull towards control as a substitute for, rather than a reflection of, commitment (also see Russell, 2008a).

While such templates may be useful, it is important to recognise that Indian call centres differ in significant ways from their Western counterparts. First off, within the Indian context, it is accurate to treat call centres and customer service as an industry sui generis. In particular, third-party call centres exist solely to provide front and back office services to the customers of numerous overseas' clients. Following on from this is the sheer size of BPO operations, with third-party players employing workers in the thousands and tens of thousands (Taylor and Bain, 2005). Yet, alongside the size of this workforce stands its comparative homogeneity, with young university-educated CSRs filling the ranks of BPO workers almost entirely in full-time jobs (Batt et al., 2005b; D'Cruz and Noronha, 2006; Budhwar et al., 2006a). Other significant differences with Western call centres flow from these characteristics. For example, the servicing of overseas clients situated in different time zones to India means that work is conducted predominantly at night (Ramesh, 2004; Taylor and Bain, 2006). In contrast to their Western counterparts, Indian agents are often required to engage in identity and locational masking practices (Mirchandani, 2009) as part of servicing overseas' markets. Trade unions, as representatives of employee voice, are only just beginning to gain a toehold in contrast to Western call centres where they have some presence, particularly in the public sector (Taylor and Bain, 2006; Thite and Russell, 2007; Russell, 2008b; Taylor et al., 2009).

Indian BPOs are typically characterised by formal, structured and rationalised HRM systems with tightly controlled organisational structures. HRM plays a strategic role, with a focus on several employee involvement and commitment work practices (Budhwar et al., 2006b). Some researchers have argued that the logic of BPO, and particularly the principal/agency relationship, favours the adoption of mass production (Taylor and Bain, 2005; Batt et al., 2005a) as opposed to customised (Gutek, 1995; Batt, 2000; 2002; Batt and Moynihan, 2002) or quasi-professionalised (Frenkel et al., 1999; Korczynski, 2001) work designs. In other words, BPO favours the adoption of more routine work flows that have been standardised to a greater degree, that allow less room for discretion and have occasionally higher levels of monitoring. It could be argued that this scenario results in lower levels of job commitment on the part of Indian workers and to the correspondingly higher levels of job attrition that we observe in this industry (Taylor and Bain, 2005: 265).

In the following analysis, we will focus on aspects of the $\mathrm{BPO} /$ call centre labour process that include the themes in the succeeding sections.

\section{Workload manageability/intensity}

In call centres, the organisation of work takes the individual employee as the unit of analysis and measures performance by such metrics as call handling time and the number of customers served per day (Batt et al., 2005b). The employee perception of workload and the fairness of such targets are important considerations particularly in a call centre environment where, on the one hand, technologies allow for high levels of standardisation and the scripting of texts to increase efficiencies, but on the other hand, employees frequently complain of boredom or stress from high levels of routinisation and repetition (Holman et al., 2007). Because offshore business models are primarily 
driven by cost-reduction strategies and are subject to stringent quality controls in service-level agreements, there is likely to be heightened tension between quantity and quality or volume and value (Taylor and Bain, 2006).

\section{Job discretion}

This refers to the amount of choice that agents have when doing job tasks (Holman et al., 2007). Research suggests that firms mostly tend to outsource non-core business processes that involve low-value, low-skilled, routine and standardised transactional activities (Thite, 2008) and more so with offshored BPO activity (Batt et al., 2005a; Taylor and Bain, 2006; Ofreneo et al., 2007). Considering that Indian CSRs are, on average, more highly educated than their counterparts in Western centres, it is possible that their skills are being under-utilised, leading to demotivation and higher quit rates. This is supported by research that finds Indian CSRs nominating lack of career opportunities as one of the key reasons for quitting their jobs (DQ-IDC, 2004; Budhwar et al., 2006a,b).

\section{Performance monitoring}

Performance monitoring tends to be more intense in call centres where technological aids such as silent/remote monitoring and screen capture tools enable the on-going collection of individual productivity data including detailed information on call handling times, agent availability and adherence to rostered break time (Holman et al., 2007). Studies of Indian call centre workflows suggest that because of the adoption of extreme forms of mass production models, employee performance is extensively and intensively monitored and measured via service level agreements that clearly specify quantitative and qualitative targets (Datta, 2004; Taylor and Bain, 2006: 46).

\section{Issues specific to Indian call centres}

Certain specific issues relating to the work environment in Indian call centres have been attributed to employee stress, burnout and turnover, and these include servicing overseas customers with different cultural and economic backgrounds, adoption of pseudo-names to mask identity (Mirchandani, 2009), customer abuse driven by the political backlash to outsourcing, working in night shift (Budhwar et al., 2006a,b) and long commuting times to and from work because of poor urban infrastructure. Each of these themes is explored in greater detail in the succeeding sections.

\section{Methodology}

Considering the dearth of empirical research on Indian call centres under the broad umbrella of offshored $\mathrm{BPO}$, we adopted a case study approach to our exploratory study. We designed and administered an extensive employee survey that covered major aspects of work organisation, supplemented by in-depth interviews with HR managers and operations managers.

We collected data over two trips to India in 2005. During the first visit, we made industry contacts, briefly interviewed senior managers to identify broad trends in employment relations in the industry and obtained in-principal approval from a number of organisations to participate in the study. Following these approaches, we developed a workforce survey to explore and analyse the issues that had been revealed in the initial contacts. This survey instrument was designed and agreed upon prior to our return visit back to the same companies in late 2005. During the second visit, we delivered the surveys to HR departments for subsequent distribution to employees working in a customer service role. Instructions were provided that only workers who had been in employment for a minimum of three months and who occupied a nonsupervisory role were to complete the self-administered questionnaire. The survey was composed of 86 questions, including banks of several Likert scale sub-questions that made for a total of 231 variables. Minimally, it required at least 30 minutes to complete, 
but in many cases, it was longer. Given that the workers undertook the survey in their own time (i.e. during breaks or at home), we are confident that the results reflected the true perceptions of the respondents at the time of completion. Confidence in the reliability of the data was further borne out in the results that were obtained, where it can be seen that the workers were open about the nature of their work and their place within it, including their likelihood of remaining in the job and their views on how the work is designed and executed (see next section).

Although the four participating call centre/BPO firms operated in multiple locations in India, research was carried out on the basis of individual work sites. For three of the companies, the surveys were distributed and completed at a single location (Bangalore, in the case of the two firms, and Hyderabad, for the third) whereas the employees at two locations (Pune and Gurgaon, near New Delhi) provided responses in the case of the fourth case study. A total of 638 surveys were returned to us. As our employment data were based on company-wide aggregations but the survey was conducted at the level of individual work sites, accurate response rates cannot be calculated. For the purposes of this paper, we will only identify the participating companies as BPO1, $\mathrm{BPO} 2, \mathrm{BPO} 3$ and $\mathrm{BPO}$. The returns from each site are as follows: $\mathrm{BPO} 1,44 ; \mathrm{BPO} 2,160$; $\mathrm{BPO} 3,257$; and $\mathrm{BPO} 4,177$. Additional descriptive information is provided on each of the case study sites in the following section.

The workforce survey questionnaire contains several sections, composed of both five-point Likert scale questions and other close-ended queries. The survey was designed specifically to elicit information about the Indian call centre/BPO sector. In this paper, we highlight four specific aspects of work that have figured in previous accounts of BPO, namely:

1. Workload manageability: here, we consider the pace and intensity of work, which are directly related to the perceived fairness of the work-effort bargain. It deals with managing quantity and quality of work against management targets.

2. Job discretion: it includes employee-initiated control over the pace of work, flexibility in addressing customer queries, the extent of adherence to scripts, task variety in work and encouragement to come up with new ideas for improvement. As discretion is sometimes, although not always, related to work skills, this theme also includes opportunities to utilise existing skills as well as the potential to develop new skills.

3. Performance monitoring: our questions sought employee feedback on the need, extent, choice and usefulness of monitoring mechanisms employed by management.

4. Issues specific to Indian call centres: These cover specific aspects unique to Indian call centres, such as adopting pseudo-names, dealing with overseas customers, racism, working night shifts and transport arrangements to and from work.

We also conducted semi-structured qualitative interviews with the managerial staff from each of the four participating BPOs. These interviews involved the use of separate protocols of open-ended questions for the HR management team and the operations management side of the business, respectively. Detailed data on general business profiles and relations with clients, employee costs, work design and recruitment challenges were collected in these sessions. In total, 15 interviews were held, sometimes with one manager and sometimes with the manager and other members of his/her team. The responses to our questions were entered by both researchers onto separate interview protocol sheets, and afterwards, the results were aggregated into interview files. We used these data to provide readers with background information on each of the organisations in the following section.

\section{Case study organisations}

All four of the case study organisations covered in this paper are indigenous thirdparty ITES/BPO providers, which is to say that each is an Indian-owned and -operated transnational entity. In three of the cases, the company is a spin-off subsidiary of a 
parent Indian IT company, while in the fourth case, an existing ITES firm was acquired by an existing corporation. Employment at the time of our study ranged from 1,700 agents (BPO1), to 2,600 (BPO2), to 5,300 (BPO3) and finally, up to 12,500 CSRs (BPO4). The latter three organisations currently rank in the top 15 indigenous third-party ITES/BPO providers in India (NASSCOM, 2006b). At each company, workers are employed across multiple sites often located in different cities, with the largest provider composed of seven different facilities in five major cities.

A defining feature of Indian BPO firms is the multifunctional character of their operations. In the literature on call centres, it is common to distinguish between inbound customer service and outbound centres as well as between front office customer care and back office processing. The Indian operations include all of the aforementioned under the concept of BPO. For example, among our case studies, BPO2 included a workforce that was divided up among inbound, outbound and back office work into a ratio of 40:40:20. Meanwhile, at BPO1, a 50/50 split between voice services and back office work was exhibited. The largest company in the study classified 60 per cent of its employees as call centre CSRs, while only 20 per cent of the employees in $\mathrm{BPO} 3$ were dedicated to this type of work.

Each of the companies examined here served a variety of overseas clients, which contributes to the complexity of analysing work in the BPO model. As a consequence of the size of these operations and the numbers of foreign business clients served, the number of process teams in each organisation is also large. At one of the companies, between 200 and 220 CSR process teams spread across three sites worked on behalf of 20 foreign business clients, half of whom were Fortune 500 companies. Each client represents a separate business process replete with its own key performance indicators specified in service-level agreements. Although it has been suggested that this arrangement makes for greater work standardisation and monitoring (Taylor and Bain, 2004; 2005; 2006; Batt et al., 2005a), the managers interviewed for this study did not necessarily concur with the standardisation part of the argument. Greater attention seemed to be paid to call management on the part of the CSR than to narrow adherence to scripts, especially with inbound calls.

Of the 638 workers who responded to our survey, an overwhelming 90 per cent were between 20 and 30 years of age and 83 per cent were single. The centres exhibited mixed gender work forces: 61 per cent of the respondents were male and 39 per cent female. The overwhelming majority of the workforce are employed on a full-time basis, but few (18 per cent) record having had previous call centre experience. Almost all respondents (90 per cent) have completed at least one university degree, with 23.5 per cent holding a post-graduate degree. On average, these employees had 11 months of job tenure with their current employer. While 63.5 per cent worked in an inbound call area, 16 per cent worked in an outbound role and 20 per cent worked in both capacities.

\section{Results}

We present employee responses to five-point Likert scale questions both in raw frequencies and in percentages in three aggregated categories: agree (combining mostly agree and strongly agree), disagree (mostly disagree and strongly disagree) and neutral (neither agree nor disagree). Additionally, the responses were decomposed according to whether the worker is mainly in a customer service role (inbound), is mainly in a telemarketing job (outbound) or performs a combination of both functions. For the purpose of analysis, missing data on individual items were omitted from the calculations contained in each cell. ${ }^{2}$

We begin with the issues relating to the management of workload that addresses the intensity and pace of work. As is evident from Table 1, a considerable majority of the sample considers that work expectations in terms of the volume of calls they are expected to handle have increased since they commenced employment. Over 70 per cent of the sample indicated that workloads have increased, while there are no significant differences between divisions. Such trends translate into interesting variations when it comes to assessments of workloads, with a bare majority of the sample 
JOBNAME: No Job Name PAGE: 8 SESS: 13 OUTPUT: Fri Dec 18 19:50:04 2009 SUM: BE481C65

/v2451/blackwell/journals/NTWE_v25_i1/ntwe_235

Table 1: Workload manageability

\begin{tabular}{|c|c|c|c|c|c|}
\hline \multirow[t]{2}{*}{ Item } & \multirow{2}{*}{$\begin{array}{l}\text { Type of } \\
\text { call area }\end{array}$} & \multicolumn{4}{|c|}{$\%$ (Raw frequency) } \\
\hline & & Disagree & Neutral & Agree & Total \\
\hline \multirow{3}{*}{$\begin{array}{l}\text { Since I have worked here, } \\
\text { expectations regarding } \\
\text { the number of calls } \\
\text { handled have } \\
\text { increased. }\end{array}$} & Inbound & $10.0(24)$ & $19.2(46)$ & 70.8 (170) & $100(240)$ \\
\hline & Outbound & & & & $100(63)$ \\
\hline & $\begin{array}{l}\text { Inbound and } \\
\text { outbound }\end{array}$ & $9.7(6)$ & $19.4(12)$ & $71.0(44)$ & $100(62)$ \\
\hline \multirow{3}{*}{$\begin{array}{l}\text { We have found just about } \\
\text { the right balance } \\
\text { between talk time and } \\
\text { quality customer } \\
\text { service at this call } \\
\text { centre. }\end{array}$} & Inbound & $16.5(40)$ & $24.4(59)$ & $59.1(143)$ & $100(242)$ \\
\hline & & & & & $100(60)$ \\
\hline & $\begin{array}{c}\text { Inbound and } \\
\text { outbound }\end{array}$ & $13.8(9)$ & $30.8(20)$ & $55.4(36)$ & $100(65)$ \\
\hline \multirow{3}{*}{$\begin{array}{l}\text { The work targets that I } \\
\text { am set are reasonable. }\end{array}$} & & & $14.4(38)$ & 68.1 (179) & 100 (263) \\
\hline & & & & & \\
\hline & $\begin{array}{l}\text { Inbound and } \\
\text { outbound }\end{array}$ & $17.8(13)$ & $19.2(14)$ & $63.0(46)$ & $100(73)$ \\
\hline \multirow{3}{*}{$\begin{array}{l}\text { I have an adequate } \\
\text { amount of time to meet } \\
\text { the expectations of the } \\
\text { caller. }\end{array}$} & Inbound & $19.6(50)$ & 14.5 & 65.9 (168) & $100(255)$ \\
\hline & & & & & \\
\hline & $\begin{array}{c}\text { Inbound and } \\
\text { outbound }\end{array}$ & & & & $100(72)$ \\
\hline \multirow{3}{*}{$\begin{array}{l}\text { I have an adequate } \\
\text { number of breaks over } \\
\text { the course of my } \\
\text { working day. }\end{array}$} & & & & & \\
\hline & Outbound & & & 63.9 & $100(72)$ \\
\hline & $\begin{array}{c}\text { Inbound and } \\
\text { outbound }\end{array}$ & $15.4(12)$ & $25.6(20)$ & $59(46)$ & $100(78)$ \\
\hline \multirow{3}{*}{$\begin{array}{l}\text { Management's } \\
\text { expectations of work } \\
\text { loads at this call centre } \\
\text { are reasonable. }\end{array}$} & Inbound & $25.8(67)$ & $22.3(58)$ & 51.9 (135) & $100(260)$ \\
\hline & & & & & \\
\hline & $\begin{array}{l}\text { Inbound and } \\
\text { outbound }\end{array}$ & $25.0(19)$ & $31.6(24)$ & $43.4(33)$ & $100(76$ \\
\hline \multirow{3}{*}{$\begin{array}{l}\text { This call centre requires } \\
\text { more employees, given } \\
\text { the general levels of } \\
\text { call demand. }\end{array}$} & Inbc & & & & \\
\hline & Outbound & 11.3 & 37.1 & 51.6 & $100(62)$ \\
\hline & $\begin{array}{l}\text { Inbound and } \\
\text { outbound }\end{array}$ & 14.7 (10) & $35.3(24)$ & $50.0(34)$ & $100(68)$ \\
\hline \multirow{3}{*}{$\begin{array}{l}\text { I feel as though I am } \\
\text { under a great deal of } \\
\text { pressure in my job. }\end{array}$} & Inbound & & $28.6(75)$ & 35.9 (94) & $100(262)$ \\
\hline & & & & & \\
\hline & $\begin{array}{l}\text { Inbound and } \\
\text { outbound }\end{array}$ & $32.4(24)$ & $37.8(28)$ & $29.7(22)$ & $100(74)$ \\
\hline \multirow{3}{*}{$\begin{array}{l}\text { After completing a call, I } \\
\text { have sufficient time to } \\
\text { complete any post-call } \\
\text { wrap-up work }\end{array}$} & Inbound & & & & $100(246)$ \\
\hline & & & & & \\
\hline & $\begin{array}{c}\text { Inbound and } \\
\text { outbound }\end{array}$ & $31.4(22)$ & $31.4(22)$ & $37.1(26)$ & $100(70)$ \\
\hline \multirow{3}{*}{$\begin{array}{l}\text { I am expected to do } \\
\text { post-call wrap-up work } \\
\text { while I am still on the } \\
\text { phone with the caller. }\end{array}$} & & & & & $100(244)$ \\
\hline & & & & & \\
\hline & $\begin{array}{c}\text { Inbound and } \\
\text { outbound }\end{array}$ & $28.4(19)$ & $32.8(22)$ & $38.8(26)$ & $100(67)$ \\
\hline \multirow{3}{*}{$\begin{array}{l}\text { Wrap-up time is } \\
\text { managed fairly at this } \\
\text { centre. }\end{array}$} & Inbound & 21.8 & $28.9(6$ & $49.4(118)$ & $100(239)$ \\
\hline & & & & & \\
\hline & $\begin{array}{l}\text { Inbound and } \\
\text { outbound }\end{array}$ & $17.6(12)$ & $33.8(23)$ & $48.5(33)$ & $100(68)$ \\
\hline
\end{tabular}


(51.7 per cent) indicating that their loads are reasonable and considerable disparity between those working in outbound telemarketing positions and the rest. Here, it seems that broader work roles combining both service and sales functions are equated with more demanding or less reasonable expectations. The sample is more divided, almost evenly into thirds, as to whether or not a great deal of pressure is experienced in the job. Again, job pressure seems to be more closely associated with the service and the blended roles compared with the sales positions. As a consequence of these patterns, it is not surprising that a sizeable majority of the sample (60.6 per cent) considers that there is a need for more employees in their work processes.

On more specific aspects of the labour process, we also witness significant variation around employee perceptions. Thus, there is an approximately 60:40 divide as to whether the number and length of break time is adequate and a similar split between those who consider that the work has been designed to offer the right balance between the quantity of call volumes agents are expected to handle and the quality of service they are expected to provide (i.e. 61 per cent satisfied with the trade-off and 39 per cent either dissatisfied or unsure). In some instances, the size of the unsure category could reflect relatively short job tenures, where workers do not have much to compare their current jobs with and where their perceptions are still actively under construction. There is also considerable concern with the ways in which non-talk time or so-called 'wrap' time (i.e. call wrap-up work) is managed. While 45 per cent of the respondents consider that they have sufficient time allotted by management for these tasks, 35 per cent dissent from this position. In service roles, almost as many respondents indicated that they are not given adequate wrap-up time as nominate satisfactory arrangements. Meanwhile, a majority of workers suggests that a managerial expectation is that wrap-up work will be conducted and finalised while calls are still in progress and this is especially true of workers who are providing voice-based customer service. Such expectations have the immediate effect of intensifying work effort by combining different elements of the job cycle so as to better churn through high call volumes. As a result, a bare majority of the sample considers that working time around the job cycle and wrap-up work in particular is managed fairly, while fewer than 50 per cent of the workers in customer service or blended service and sales roles consider this to be the case.

Overall, our data on perceptions of expected work effort, work norms and workload manageability suggest considerable levels of disquiet. A substantial proportion of the sample experiences intense, stress-producing work conditions that are at odds with the images of professionalised knowledge work that is often projected by the BPO industry. Considering other aspects of the work such as the discretion and autonomy that it allows workforces to express and the skills that it uses and creates adds further to our picture of the realities of BPO.

Job discretion and skills are other key elements of work organisation that impact on job quality. The upper half of Table 2 examines various indicators of job discretion. Just over half (55 per cent) of the total respondents agreed that they possessed some leeway to vary the pace at which they worked over the course of a shift, but this feature is vitiated by other aspects of the work, where a considerably greater proportion of the sample consider that their work is too closely scripted (39 per cent in agreement versus 29 per cent in disagreement) and a greater proportion disagreeing that they have a lot of discretion in the ways that they respond to the public as opposed to possessing this type of decision-making autonomy ( 39 per cent versus 27 per cent). Some of these results do show significant variation depending upon whether the worker is in customer service, sales or performs both tasks. For example, the telemarketers are least likely to agree that they have much discretion, whereas workers in service roles are more likely to admit to having some discretion. Similarly, telemarketing workers are significantly more likely to agree that their conversations are too closely scripted.

With respect to perceptions of skill, tellingly, just over a third of the sample consider that their current jobs are making full use of their educational qualifications and experience. For both telemarketers and workers in dual servicing and sales positions, a greater proportion disagrees that the jobs are fully employing their qualifications than 
JOBNAME: No Job Name PAGE: 10 SESS: 13 OUTPUT: Fri Dec 18 19:50:04 2009 SUM: AE1CB854

/v2451/blackwell/journals/NTWE_v25_i1/ntwe_235

Table 2: Job discretion

\begin{tabular}{|c|c|c|c|c|c|}
\hline \multirow[t]{2}{*}{ Item } & \multirow{2}{*}{$\begin{array}{l}\text { Type of } \\
\text { call area }\end{array}$} & \multicolumn{4}{|c|}{$\%$ (R frequency) } \\
\hline & & Disagree & Neutral & Agree & Total \\
\hline \multirow{3}{*}{$\begin{array}{l}\text { It is possible for me } \\
\text { to vary the pace } \\
\text { that I work at- } \\
\text { more quickly or } \\
\text { less quickly when } \\
\text { I feel like it. }\end{array}$} & Inbound & $16.8(43)$ & $26.2(67)$ & $57.0(146)$ & $100(256)$ \\
\hline & Outbound & $19.1(13)$ & 30.9 (21) & $50.0(34)$ & $100(68)$ \\
\hline & $\begin{array}{c}\text { Inbound and } \\
\text { outbound }\end{array}$ & $16.7(12)$ & $29.2(21)$ & $54.2(39)$ & $100(72)$ \\
\hline \multirow{3}{*}{$\begin{array}{l}\text { I have a lot of } \\
\text { discretion in } \\
\text { responding to } \\
\text { customers' } \\
\text { questions. }\end{array}$} & Inbound & $40.3(102$ & $29.6(75)$ & $30.0(76)$ & $100(253)$ \\
\hline & Outbound & & $35.6(21)$ & & $100(59)$ \\
\hline & $\begin{array}{c}\text { Inbound and } \\
\text { outbound }\end{array}$ & $31.7(26)$ & $46.3(38)$ & $22.0(18)$ & $100(82)$ \\
\hline \multirow{3}{*}{$\begin{array}{l}\text { I feel that my } \\
\text { conversations with } \\
\text { customers are too } \\
\text { closely scripted }\end{array}$} & Inbound & $32.1(79)$ & $32.9(81)$ & $35.0(86)$ & $100(246)$ \\
\hline & Outbound & & & & $100(63)$ \\
\hline & $\begin{array}{c}\text { Inbound and } \\
\text { outbound }\end{array}$ & $24.0(18)$ & $34.7(26)$ & $41.3(31)$ & \\
\hline \multirow{3}{*}{$\begin{array}{l}\text { We are encouraged } \\
\text { to come up with } \\
\text { new and better } \\
\text { ways to do our } \\
\text { job. }\end{array}$} & Inbound & & & 69.3 & $100(277)$ \\
\hline & & & & & \\
\hline & $\begin{array}{c}\text { Inbound and } \\
\text { outbound }\end{array}$ & $13.1(11)$ & $25.0(21)$ & $61.9(52)$ & $100(84)$ \\
\hline \multirow{3}{*}{$\begin{array}{l}\text { This job makes full } \\
\text { use of my } \\
\text { education and } \\
\text { experience. }\end{array}$} & Inbound & $34.4(94)$ & $24.2(66)$ & 41.4 (113) & $100(273)$ \\
\hline & & & & & $100(75)$ \\
\hline & $\begin{array}{c}\text { Inbound and } \\
\text { outbound }\end{array}$ & $36.5(31)$ & $30.6(26)$ & $32.9(28)$ & $100(85)$ \\
\hline \multirow{3}{*}{$\begin{array}{l}\text { I am satisfied with } \\
\text { the opportunities } \\
\text { that this job gives } \\
\text { me to make use of } \\
\text { my skills. }\end{array}$} & Inbound & & & & $100(279)$ \\
\hline & Outbound & & & $41.1(30)$ & \\
\hline & $\begin{array}{c}\text { Inbound and } \\
\text { outbound }\end{array}$ & $39.3(35)$ & $25.8(23)$ & $34.8(31)$ & $100(89)$ \\
\hline \multirow{3}{*}{$\begin{array}{l}\text { There are } \\
\text { opportunities for } \\
\text { me to advance } \\
\text { myself in this call } \\
\text { centre. }\end{array}$} & Inboun & $17.5(48)$ & $17.8(49)$ & $64.7(178)$ & $100(275)$ \\
\hline & Outbor & & & 59. & $100(72)$ \\
\hline & $\begin{array}{c}\text { Inbound and } \\
\text { outbound }\end{array}$ & $21.8(19)$ & 21.8 (19) & $56.3(49)$ & $100(87)$ \\
\hline \multirow{3}{*}{$\begin{array}{l}\text { My work has a lot of } \\
\text { variety in it. }\end{array}$} & Inbound & $27.0(74)$ & 23.7 (65) & 49.3 (135) & $100(274)$ \\
\hline & & 23.6 (17) & $27.8(20)$ & $48.6(35)$ & $100(72)$ \\
\hline & $\begin{array}{c}\text { Inbound and } \\
\text { outbound }\end{array}$ & $32.6(29)$ & $25.8(23)$ & 41.6 (37) & $100(89)$ \\
\hline \multirow{3}{*}{$\begin{array}{l}\text { My job could be } \\
\text { designed to be } \\
\text { more interesting. }\end{array}$} & Inbound & $7.8(21)$ & $20.1(54)$ & 72.1 (194) & $100(269)$ \\
\hline & & & & & $100(68)$ \\
\hline & $\begin{array}{c}\text { Inbound and } \\
\text { outbound }\end{array}$ & $10.2(9)$ & 30.7 (27) & $59.1(52)$ & $100(88)$ \\
\hline \multirow{3}{*}{$\begin{array}{l}\text { This job is } \\
\text { monotonous }\end{array}$} & Inbound & $21.2(49)$ & $29.4(68)$ & 49.4 (114) & $100(231)$ \\
\hline & Outbound & $20.6(13)$ & $36.5(23)$ & $42.9(27)$ & $100(63)$ \\
\hline & $\begin{array}{c}\text { Inbound and } \\
\text { outbound }\end{array}$ & $19.0(12)$ & $34.9(22)$ & $46.0(29)$ & $100(63)$ \\
\hline
\end{tabular}

10 New Technology, Work and Employment

C 2009 Blackwell Publishing Ltd 
agree with this statement. Again, only a minority of the total sample (43 per cent) registers satisfaction with the opportunities that the work presents for using their existing skills. Interestingly, the workers who perform both service and sales work are less satisfied with the opportunities to realise their skills at work than those who perform just one function. Seemingly then, broader jobs do not necessarily guarantee a more expansive use of skills in the eyes of these workers. Reinforcing these themes, less than half of the respondents (47.6 per cent) admit to their work to have considerable variety in it, while the largest proportion (48 per cent) considers their job to be monotonous, with no significant variation between inbound, outbound and blended functions. Given these observations, it is little wonder that a considerable majority considers that the jobs could be redesigned to be more interesting. This last feature is especially prominent for the customer service workers, 72 per cent of whom state that the jobs could be improved upon.

As other investigations have shown (Lankshear et al., 2001), most of the workers accept the principle of monitoring in the call centre environment and BPO employees in this study agree, with fewer than 15 per cent of the sample either opposed to or unsure about the necessity of monitoring (not shown in Table 3). Given this overall in-principle agreement, the employee responses to monitoring then come down to such factors as to how it is conducted and for what purposes. Among our sample, very few have any say into how they will be monitored. For example, the workers are not normally given a choice as to whether monitoring will be conducted in an open, side-by-side fashion (double jacking) or whether it will be remote and unannounced. Overall, a greater proportion indicate that they do not receive what they would consider to be reasonable notification as to when monitoring will occur than vice versa (50 per cent versus 32 per cent). On the other hand, a large majority indicates receiving useful performance feedback on the basis of the monitoring they are subjected to. This would indicate that monitoring is used more for training and coaching than for disciplinary purposes. Supporting this hypothesis further are indications that monitoring is not highly correlated with job stress. Between a fifth and a quarter of the sample, depending upon the type of call centre work performed associates monitoring with job stress. Overall, approximately two-thirds of the respondents are satisfied with the way that monitoring is practiced in their work, with no significant differences in terms of the types of call centre work undertaken. In short, the issues that our sample of BPO workers have with the work they perform is not principally associated with the question of monitoring.

Finally, we consider some specific issues that are unique to working in Indian call centres (Table 4). First of all, viewpoints are divided on the topic of working night shifts. The largest group (44 per cent) do not have objections to working nights, while 28 per cent do not enjoy such conditions and a further 28 per cent are undecided. Similar to some other aspects of BPO work such as monitoring, it would seem as though night work is simply defined as part of the job for many who undertake employment in the sector. For the most part, the workers register satisfaction with the transportation arrangements to and from work that the employers offer them.

While just over a quarter of the sample admits to having been subjected to customer abuse, when this is made more specific and framed in terms of racist remarks, close to 40 per cent indicate that they have been on the receiving end of such behaviour. A larger proportion of the sample have been the objects of racism associated with their work than not with no significant differences when the type of call centre work is controlled for. The workers are less certain about the identity-masking practices that they may be asked to invoke. While 45 per cent of the sample do not register objections to assuming a fictitious identity for the purposes of carrying out their work, a third are undecided about this practice and a further 22 per cent disapprove of it. Interestingly, this aspect of conducting BPO is not as widely accepted as is call monitoring. For some, although clearly not for all, identity masking is yet another aspect of doing the job.

It is possible that such features of the work as racial abuse and identity masking may add to the levels of emotional labour that are associated with outsourced, offshore call centre work. When queried, the largest element of the sample (45 per cent) indicated 
Table 3: Performance monitoring

\begin{tabular}{|c|c|c|c|c|c|}
\hline \multirow[t]{2}{*}{ Item } & \multirow{2}{*}{$\begin{array}{l}\text { Type of } \\
\text { call area }\end{array}$} & \multicolumn{4}{|c|}{$\%$ (R frequency) } \\
\hline & & Disagree & Neutral & Agree & Total \\
\hline \multirow{3}{*}{$\begin{array}{l}\text { Management is too } \\
\text { focused on call } \\
\text { handling statistics } \\
\text { at this call centre. }\end{array}$} & Inbound & $11.2(27)$ & $22.0(53)$ & $66.8(161)$ & $100(241)$ \\
\hline & Outbound & $8.1(5)$ & $8.1(5)$ & $83.9(52)$ & $100(62)$ \\
\hline & $\begin{array}{l}\text { Inbound and } \\
\text { outbound }\end{array}$ & $19.1(13)$ & $32.4(22$ & $48.5(33)$ & $100(68)$ \\
\hline \multirow{3}{*}{$\begin{array}{l}\text { I get a reasonable } \\
\text { notice as to when I } \\
\text { will be monitored. }\end{array}$} & Inbound & 55.7 (137) & $16.7(41)$ & $27.6(68)$ & $100(246)$ \\
\hline & Outbound & $32.2(19)$ & $20.3(12)$ & $47.5(28)$ & $100(59)$ \\
\hline & $\begin{array}{c}\text { Inbound and } \\
\text { outbound }\end{array}$ & $41.5(27)$ & 26.2 (17) & $32.3(21)$ & 100 (65) \\
\hline \multirow{3}{*}{$\begin{array}{l}\text { I am able to have a } \\
\text { choice in the type } \\
\text { of monitoring } \\
\text { (silent or side-by- } \\
\text { side) that I am } \\
\text { subject to. }\end{array}$} & Inbound & $68.6(164)$ & $14.2(34)$ & $17.2(41)$ & $100(239)$ \\
\hline & Outbound & $39.0(23)$ & 33.9 (20) & $27.1(16)$ & $100(59)$ \\
\hline & $\begin{array}{l}\text { Inbound and } \\
\text { outbound }\end{array}$ & $50.8(33)$ & $24.6(16)$ & $24.6(16)$ & $100(65)$ \\
\hline \multirow{3}{*}{$\begin{array}{l}\text { I receive useful } \\
\text { feedback about the } \\
\text { results of my } \\
\text { monitored calls. }\end{array}$} & Inbound & $9.0(22)$ & $11.4(28)$ & 79.6 (195) & $100(245)$ \\
\hline & Outbound & $4.9(3)$ & $8.2(5)$ & 86.9 (53) & $100(61)$ \\
\hline & $\begin{array}{l}\text { Inbound and } \\
\text { outbound }\end{array}$ & $7.4(5)$ & 19.1 (13) & $73.5(50)$ & $100(68)$ \\
\hline \multirow{3}{*}{$\begin{array}{l}\text { I am satisfied with } \\
\text { the way in which } \\
\text { call monitoring is } \\
\text { used in this centre. }\end{array}$} & Inbound & $13.8(34)$ & 21.5 & $64.8(160)$ & $100(247)$ \\
\hline & Outbound & $8.5(5)$ & 25.4 & $66.1(39)$ & $100(59)$ \\
\hline & $\begin{array}{c}\text { Inbound and } \\
\text { outbound }\end{array}$ & $11.9(8)$ & $31.3(21)$ & $56.7(38)$ & $100(67)$ \\
\hline \multirow{3}{*}{$\begin{array}{l}\text { Call monitoring } \\
\text { stresses me out. }\end{array}$} & Inbound & $52.7(126)$ & $22.2(53)$ & $25.1(60)$ & 100 (239) \\
\hline & Outbound & $44.1(26)$ & 32.2 (19) & $23.7(14)$ & $100(59)$ \\
\hline & $\begin{array}{c}\text { Inbound and } \\
\text { outbound }\end{array}$ & $49.3(33)$ & $29.9(20)$ & $20.9(14)$ & $100(67)$ \\
\hline \multirow{3}{*}{$\begin{array}{l}\text { I find my } \\
\text { performance } \\
\text { reviews to be } \\
\text { stressful }\end{array}$} & & $37.4(82)$ & $33.8(74)$ & $28.8(63)$ & $100(219)$ \\
\hline & Outbound & 28.3 & $40.0(24)$ & 31.7 (19) & $100(60)$ \\
\hline & $\begin{array}{c}\text { Inbound and } \\
\text { outbound }\end{array}$ & $31.3(20)$ & $35.9(23)$ & $32.8(21)$ & $100(64)$ \\
\hline
\end{tabular}

that they have to emotionally detach themselves from the work. This type of self-control often involves having to mask one's feelings when in interaction with a foreign public. Thus, an even greater proportion (54 per cent, with no significant differences between different job roles within call centre work) admits to having to hide inner feelings. Such emotional labour though need not necessarily compromise self-identities. Overall, a majority indicates feeling that they can be their real selves while performing their work. Interestingly, the workers in sales roles are especially confident in this regard. Here, it may be the case that 'entrepreneurial' work is well aligned with the entrepreneurial identities that workers in these roles take on. On the other hand, workers who are responsible for both service and sales functions exhibit considerably less assurance in these matters.

So far, our findings have suggested significant contradictions to the ways in which BPO has been constructed. Such contradictions involve interactive effects between the industry labour market-who is hired-and the sort of work that is then undertaken - the nature of the labour process that the hires are subjected to. Indian society's highly educated cohorts take up jobs that allow little room for discretion, 
Table 4: Work issues specific to Indian call centres

\begin{tabular}{|c|c|c|c|c|c|}
\hline \multirow[t]{2}{*}{ Item } & \multirow{2}{*}{$\begin{array}{l}\text { Type of } \\
\text { call area }\end{array}$} & \multicolumn{4}{|c|}{$\%$ (R frequency) } \\
\hline & & Disagree & Neutral & Agree & Total \\
\hline \multirow{3}{*}{$\begin{array}{l}\text { If you are expected/ } \\
\text { encouraged to adopt } \\
\text { a pseudo-name, how } \\
\text { do you feel about it? }\end{array}$} & Inbound & $21.4(43)$ & $30.3(61)$ & 48.3 (97) & $100(201)$ \\
\hline & Outbound & & & & 100( \\
\hline & $\begin{array}{c}\text { Inbound and } \\
\text { outbound }\end{array}$ & $23.3(14)$ & $35.0(21)$ & & $100(60)$ \\
\hline \multirow{3}{*}{$\begin{array}{l}\text { I have to put up with } \\
\text { quite a lot of abuse } \\
\text { from my customers }\end{array}$} & Inbound & $35.6(72)$ & $35.1(71)$ & $29.2(59)$ & $100(202)$ \\
\hline & Outbou & $3608-2$ & $30.0(15)$ & 34.0 & $100(50)$ \\
\hline & $\begin{array}{l}\text { Inbound and } \\
\text { outbound }\end{array}$ & $42.9(24)$ & $39.3(22)$ & $17.9(10)$ & $100(56)$ \\
\hline \multirow{3}{*}{$\begin{array}{l}\text { I sometimes encounter } \\
\text { racism when dealing } \\
\text { with overseas } \\
\text { customers }\end{array}$} & Inbound & $31.8(69)$ & $28.6(62)$ & $39.6(86)$ & 100 (217) \\
\hline & Outbound & & & & $100(54)$ \\
\hline & $\begin{array}{l}\text { Inbound and } \\
\text { outbound }\end{array}$ & $28.1(16)$ & $35.1(20)$ & $36.8(21)$ & 100 (57) \\
\hline \multirow{3}{*}{$\begin{array}{l}\text { I enjoy working in } \\
\text { night shifts. }\end{array}$} & Inbound & & & & $100(224)$ \\
\hline & & & & & 100 \\
\hline & $\begin{array}{c}\text { Inbound and } \\
\text { outbound }\end{array}$ & $28.8(19)$ & $34.8(23)$ & $36.4(24)$ & $100(66)$ \\
\hline \multirow{3}{*}{$\begin{array}{l}\text { The company provides } \\
\text { satisfactory transport } \\
\text { arrangements for } \\
\text { those working } \\
\text { during odd hours. }\end{array}$} & Inbound & $0.5(48)$ & $13.2(31)$ & 66.2 (155) & $100(234)$ \\
\hline & Outbound & 134 (9) & $7.5(5)$ & 79.1 (53) & $100(67)$ \\
\hline & $\begin{array}{c}\text { Inbound and } \\
\text { outbound }\end{array}$ & $32.4(22)$ & $20.6(14)$ & 47.1 (32) & $100(68)$ \\
\hline \multirow{3}{*}{$\begin{array}{l}\text { I have to become } \\
\text { emotionally } \\
\text { detached from } \\
\text { callers when I am } \\
\text { responding to them. }\end{array}$} & Inbound & 20.9( & $34.0(83)$ & $45.1(110)$ & $100(244)$ \\
\hline & & & & & $100(53)$ \\
\hline & $\begin{array}{c}\text { Inbound and } \\
\text { outbound }\end{array}$ & $25.0(18)$ & $33.3(24)$ & $41.7(30)$ & $100(72)$ \\
\hline \multirow{3}{*}{$\begin{array}{l}\text { I have to mask my true } \\
\text { feelings when I am } \\
\text { dealing with callers }\end{array}$} & Inbound & $13.2(32)$ & $30.6(74)$ & $56.2(136)$ & $100(242)$ \\
\hline & & & & & $100(55)$ \\
\hline & $\begin{array}{c}\text { Inbound and } \\
\text { outbound }\end{array}$ & $16.7(12)$ & $36.1(26)$ & $47.2(34)$ & $100(72)$ \\
\hline \multirow{3}{*}{$\begin{array}{l}\text { I can be my true self } \\
\text { when I am on the } \\
\text { phone with callers. }\end{array}$} & & $21.3(51)$ & $27.6(66)$ & $51.0(122)$ & 100 (239) \\
\hline & Outbound & $8.8(5)$ & 21.1 (12) & $70.2(40)$ & $100(57)$ \\
\hline & $\begin{array}{l}\text { Inbound and } \\
\text { outbound }\end{array}$ & $12.5(9)$ & $45.8(33)$ & $41.7(30)$ & $100(72)$ \\
\hline
\end{tabular}

while presenting only limited opportunities to use existing educational achievements or to develop new skills. The positions are, however, demanding in terms of the workload expectations (work intensity and work duration) and in respect of the emotional labour and associated stress that are exacted from dealing with overseas' publics. Existing attrition levels, which were reported to be between 70 and 120 per cent per annum at three out of our four case study sites are testimony to these realities. ${ }^{3}$ Attrition levels are also something of 'a moment of truth' for management.

In our interviews with HR and operations managers about the business environment, labour market conditions and HR policies and practices at the case study organisations, it was indicated that attracting employable workers and then holding on to 
them was the 'main order of business'. What is challenging for HR managers in BPO is that the industry, and call centre employment in particular, suffers from a social stigma partly associated with the factors discussed earlier. Consequently, it is not seen as a stable, long-term or socially prestigious employment but rather as an ad hoc, lowesteem job.

The HR managers provided several examples to demonstrate that the industry is adopting what are currently considered to be best practices in people management including the utilisation of performance bonuses, the organisation of social events and transport services to and from home, the use of food vouchers for on-site cafeterias and the granting of educational scholarships to purse further study. Referral bonuses that are paid to workers who help in the recruitment of new workers is now a common practice as is the convening of 'town hall' meetings to listen to grievances and suggestions for improvement. While these measures tackle some work-related issues, they do not directly address some of the more acute problems identified earlier, including the long-term career prospects that are valued by employees. Here, many managers pointed out that while they have an active internal promotion policy they can only promote a limited number of employees, causing further frustration and employee turnover. According to these managers, the nature of BPO means that the industry generally lacks the flexibility to provide meaningful job enrichment to its incumbents. Meanwhile, part-time employment and flexi-hours are rarely practiced because of the impracticalities of enacting such programmes in the context of employer-organised transportation to work.

Going up the value chain by diversifying into higher value BPO activities is seen as another way to engage and retain employees. However, specialist call centre services in data mining, accountancy, equity research and other specialised services require special domain knowledge and expertise and are out of bound for generalists, which many CSRs are. The HR manager in one company with a much lower employee attrition rate than others covered in this study claimed that by developing long-term relationships with certain large and well-diversified overseas clients, his company was able to achieve business stability and offer promotional opportunities to well-performing employees to move into higher value-added functions. This strategy remained the exception rather than rule among the case study firms.

\section{Discussion and implications}

In this paper, we have moved beyond the hype associated with offshoring services to India to examine how those who are responsible for executing the work view it. The general theme of most of the previous research on employment relations in Indian call centres is that the inherent cost-reduction nature of the outsourcing model leads to greater levels of work standardisation, which in turn is accompanied by high levels of performance monitoring and low levels of job discretion (Batt, 2000; 2002; Batt et al., 2005a,b; 2006, Taylor and Bain, 2005; 2006). Our study extends this research by examining how workers interpret outsourced, offshore interactive service work.

In terms of workloads, while there is acknowledgement that they are demanding, there is also reluctance on the part of many to admit to being unable to cope. As a result, the workforce is almost evenly split between those who consider current workloads to be reasonable and those who think otherwise. A similar rift occurs around the issue of work pressure. There is less concern over the question of monitoring, although even here, only a bare majority denies that monitoring creates associated job stresses.

If results with respect to workloads and monitoring are mixed in the ways indicated earlier, this is less the case with regard to the work being capable of fulfilling occupational expectations. On this score, there is little ambiguity. Our study supports and extends previous research (DQ-IDC, 2004; Batt et al., 2005a,b; also see Budhwar et al., $2006 a, b)$ findings that there is a mismatch between employee education profiles and the skills required to undertake much of what falls under BPO. Fewer employees in our survey believed that their job made full use of their education and experience or that it provided satisfactory outlets for using their qualifications than responded in a positive 
fashion. Given the $\mathrm{BPO}$ workforce profile and employee responses to our questions about their work, a picture begins to emerge of a significant gap between what social actors bring to the job in terms of skills and expectations and what the jobs offer regarding intrinsic work satisfaction. The unique features of the workforce may render this discrepancy more severe than what has been experienced in Western call centres. If we consider that the call centre labour process mainly requires semi-skilled qualifications, then there is certainly a case to be made for a job/skill mismatch in Indian BPO. In the context of the Indian call centre/BPO industry, the opportunities for gainful employment provided by the industry for fresh graduates leads initially to a strong work commitment. However, a perceived lack of career advancement in the call centre industry motivates employees to jump from one job to another, looking for short-term gains, such as higher salaries, even though general working conditions and career prospects may remain the same between employers.

Our study essentially indicates that the major problem in BPO seems to be the mismatch between the BPO labour market and the labour process that characterises the work. This contradiction between who is hired and what is subsequently expected is not easily broached by quick HR 'fixes' of the sort discussed in the preceding section, which barely seem to scratch the surface of underlying discontent. For multinational companies and third-party vendors operating in Indian ITES/BPO, our study has several practical implications. The operations and HR managers indicated in our interviews that call centre jobs are not generally seen to be a long-term career option in India, and therefore, the attraction and especially the retention of employable labour is likely to remain a huge challenge. In mature markets, when call centre employees quit, they tend to leave the call centre industry altogether, whereas in India, many CSRs who leave simply move on to competing centres, particularly to captive operations managed by multinationals. This may be because the product range of captives is more stable and strategic HRM measures more intensive. In any event, high levels of attrition, movement between firms and labour 'poaching' are now recognisable features of Indian BPO.

This leads us to some of the limitations of the study. Our study was confined to four large ITES/BPO third-party providers and did not cover the captives where the employee turnover is believed to be lower. However, this situation might change with the sale of captives to indigenous third-party operators as outsourcing continues to deepen. Further comparative research that distinguishes between MNC captives and domestic third-party operations would be especially valuable in this regard. As well, field observations and ethnographic research would undoubtedly provide further useful insights into the lived experiences of BPO workers, although strict protocols on client confidentiality and preoccupations with security and secrecy will not make this an easy task for researchers. Further, there are significant quantitative and qualitative differences in the nature of work performed in the various types of BPO activities, such as inbound, outbound, Internet-based chat and knowledge-intensive professional services in accounting, legal, health care, engineering and other industries that need to be considered in future studies. Technological advancements such as Internet protocolenabled contact centres and changing business models such as an increased move towards contact centres becoming profit centres may further influence the nature of $H R$ challenges in this industry and the strategies to address them. Finally, while the managers in our study referred to social and family pressures in the career choice of Indian employees, such as the stigmatisation of $\mathrm{BPO} /$ call centre work, such cultural dimensions also need to be taken into account in future studies.

Through globalisation, with its footloose qualities, and under the influence of technological advancements, India appears to have been able to take advantage of the growth in an ITES/BPO sector. However, in the larger context of the Indian economy, this sector is still a faint beacon of hope. Within the industry, the notion of an endless supply of qualified personnel has to be tempered with the limited 'employability' of those who want to enter the workforce. The gap between expectations of working for slick, state-of-the-art firms catering to some of the world's best known companies and the realities of intensive work with limited occupational prospects may crash the 
dreams of employees as evidenced by high turnover. So far, the employers have kept the dream alive, but as the BPO economy matures, access to a compliant workforce may soon be a thing of the past, and HR will have to move beyond quick fixes to address fundamental challenges in the BPO employment relationship.

\section{Notes}

1. This figure includes the value of both information technology (IT) and such IT-enabled services (ITES) as call centre operations.

2. Missing data are largely a result of workers whose principal job is not voice-based phone work (i.e. voice-based service and/or telemarketing) being unable to respond to questions on the survey.

3. Attrition at the fourth case study was reported to be approximately 35 per cent. Interestingly, this was the company that conducted the least amount of call centre work. All attrition data cited in the paper are derived from our interviews with management.

\section{References}

Batt, R. (2000), 'Strategic Segmentation in Front Line Services: Matching Customers, Employees and Human Resource Management Systems', International Journal of Human Resource Management 11, 540-561.

Batt, R. (2002), 'Managing Customer Services: Human Resource Practices, Quit Rates and Sales Growth', Academy of Management Journal 45, 587-597.

Batt, R. and L. Moynihan (2002), 'The Viability of Alternate Call Centre Production Models', Human Resource Management Journal 12, 4, 14-34.

Batt, R., V. Doellgast and H. Kwon (2005a), 'Service Management and Employment Systems in U.S. and Indian Call Centres', in S. Collins and L. Brainard (eds), Brookings Trade Forum 2005: Offshoring White-Collar Work-The Issues and Implications (Washington, DC: Brookings Institute), pp. $\bullet \bullet \bullet \bullet$.

Batt, R., V. Doellgast, H. Kwon, M. Nopany and P. Nopany (2005b), The Indian Call Centre Industry: National Benchmarking Report. Strategy, HR Practices and Performance (Ithaca, New York: Cornell University).

Beck, U. (2000), What Is Globalization? (Cambridge: Polity Press).

Boltanski, L. and E. Chiapello (2005), The New Spirit of Capitalism (London: Verso).

Budhwar, P., A. Varma, V. Singh and R. Dhar (2006a), 'HRM Systems of Indian Call Centres: An Exploratory Study', International Journal of Human Resource Management 17, 5, 881-897.

Budhwar, P., H.K. Luthar and J. Bhatnagar (2006b), 'The Dynamics of HRM Systems in Indian BPO Firms', Journal of Labor Research 27, 3, 339-360.

D'Cruz, P. and E. Noronha (2006), 'Being Professional: Organisational Control in Indian Call Centres', Social Science Computer Review 24, 3, 342-361.

Datta, R.C. (2004), 'Worker and Work-A Case Study of an International Call Centre in India', Paper presented at the 22nd International Labour Process Conference, University of Amsterdam, 5-7 April.

Dicken, P. (2007), Global Shift: Mapping the Changing Contours of the World Economy (London: Sage).

DQ-IDC (2004), India BPO Employee Satisfaction Survey, http://www.bpo.nasscom.org/ artdisplay.aspx?art_id=3709andcat_id=609 (accessed December 9, 2005).

Frenkel, S., M. Korczynski, K. Shire and M. Tam (1999), On the Front Line: Organization of Work in the Information Economy, (Ithaca, NY: Cornell University IRL Press).

Gereffi, G. (1994), 'The Organization of Buyer-Driven Global Commodity Chains', in G. Gereffi and M. Korzeniewicz (eds), Commodity Chains and Global Capitalism (Westport: Praeger), pp. $\bullet \bullet-\bullet$.

Gutek, B. (1995), The Dynamics of Service: Reflections on the Changing Nature of Customer/Provider Interactions (San Francisco, CA: Jossey-Bass).

Harvey, D. (2007), A Brief History of Neoliberalism (Oxford: Oxford University Press).

Holman, D., R. Batt and U. Holtgrewe (2007), The Global Call Centre Report: International Perspectives on Management and Employment, Report of the Global Call Centre Network (US Format), http:/ / www.ilr.cornell.edu/globalcallcenter/upload/GCC-Intl-Rept-US-Version.pdf (accessed $\bullet \bullet \bullet$ ).

Houlihan, M. (2002), 'Tensions and Variations in Call Centre Management Strategies', Human Resource Management Journal 12, 4, 67-85.

Kinnie, N., S. Hutchinson and J. Purcell (2000), ' "Fun and Surveillance": the Paradox of High Commitment Management in Call Centres', International Journal of Human Resource Management 11, 5, 967-985. 
Korczynski, M. (2001), 'The Contradiction of Service Work: Call Centre as Customer-Oriented Bureaucracy', in A. Sturdy, I. Grugulis and H. Willmott (eds), Customer Service: Empowerment and Entrapment (Houndmills: Palgrave), pp. $\bullet \bullet-\bullet$.

Korczynski, M., K. Shire, S. Frenkel and M. Tam (2000), 'Service Work in Consumer Capitalism: Customers, Control and Contradictions', Work, Employment and Society 14, 4, 669-687.

KPMG (2004), Strengthening the Human Resource Foundation of the Indian IT-Enabled Services Industry, Report by KPMG in association with NASSCOM under the aegis of the Department of IT, Ministry of Information Technology and Communications, Government of India.

Lankshear, G., P. Cook, D. Mason, S. Coates and G. Button (2001), 'Call Centre Employees' Responses to Electronic Monitoring: Some Research Findings', Work, Employment and Society 15, 3, 595-605.

Mirchandani, K. (2009), 'Transnationalism in Indian Call Centres', in M. Thite and B. Russell (eds), The Next Available Operator: Managing Human Resources in Indian Business Process Outsourcing

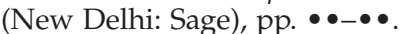

NASSCOM (2006a), Indian ITES-BPO Industry_Fact Sheet (New Delhi: National Association of Software and Service Companies).

NASSCOM (2006b), NASSCOM Announces Third Party ITES-BPO Companies Rankings for FY 05-06 (New Delhi: National Association of Software and Service Companies).

NASSCOM (2007), Indian ITES-BPO Industry_Fact Sheet (New Delhi: National Association of Software and Service Companies).

Ofreneo, R., C. Ng and $\bullet \bullet . \bullet$. Marasigan-Pasumbal (2007), 'Voice for the Voice Workers: Addressing the IR Concerns in the Call Center/BPO Industry of Asia', Indian Journal of Industrial Relations 42, 4, 534-557.

Ramesh, B.P. (2004), " "Cyber Coolies” in BPO: Insecurities and Vulnerabilities of Non-Standard Work', Economic and Political Weekly, January 31, ••, 492-497.

Russell, B. (2008a), 'Call Centres: A Decade of Research', International Journal of Management Reviews 10, 3, 195-219.

Russell, B. (2008b), 'Unions in the Information Economy: Info-Service Work and Organizing in Australian Call Centres', Journal of Industrial Relations 50, 2, 285-303.

Shah, V. and R. Band (2003), 'Capability Development in Knowledge Intensive IT Enable Services', European Journal of Work and Organizational Psychology 12, 4, 418-427.

Srivastava, S. and N. Theodore (2006), 'Offshoring Call Centres: The View from the Wall Street', in J. Burgess and J. Connell (eds), Developments in the Call Centre Industry (Abingdon, OX: Routledge), pp. $\bullet \bullet \bullet \bullet$.

Taskforce (2003), Taskforce on Meeting the Human Resources Challenge for IT and IT Enabled Services, Government of India, Ministry of Communications and Information Technology. Department of Information Technology. 18 December 2003.

Taylor, P. and P. Bain (2005), "'India Calling to the Far Away Towns": the Call Centre Labour Process and Globalisation', Work, Employment and Society 19, 2, 261-282.

Taylor, P. and P. Bain (2006), 'Work Organisation and Employee Relations in Indian Call Centres', in J. Burgess and J. Connell (eds), Developments in the Call Centre Industry (Abingdon, OX: Routledge), pp. $\bullet \bullet-\bullet$.

Taylor, P., P. D'Cruz, E. Noronha and D. Scholarios (2009), 'Union Formation in Indian Call Centres', in M. Thite and B. Russell (eds), The Next Available Operator: Managing Human Resources in Indian Business Process Outsourcing Industry (New Delhi: Sage), pp. 145-181.

Thite, M. (2008), 'Business Process Outsourcing Management Issues', in C. Wankel (ed.), The Handbook of 21st Century Management (Thousand Oaks, CA: Sage), pp. $\bullet \bullet-\bullet \bullet$.

Thite, M. and B. Russell (2007), 'India and Business Process Outsourcing', in J. Burgess and J. Connell (eds), Globalisation and Work in Asia (Oxford: Chandos Publishing), pp. $\bullet \bullet-\bullet$.

Wallace, C. (2009), 'An Overview of the Indian Contact Centre Industry', in M. Thite and R. Russell (eds), The Next Available Operator: Managing Human Resources in Indian Business Process Outsourcing Industry (New Delhi: Sage), pp. 13-32.

Wood, S., D. Holman and C. Stride (2006), 'Human Resource Management and Performance in UK Call Centres', British Journal of Industrial Relations 44, 1, 99-124. 


\section{AUTHOR QUERY FORM}

Dear Author,

During the preparation of your manuscript for publication, the questions listed below have arisen. Please attend to these matters and return this form with your proof.

Many thanks for your assistance.

\begin{tabular}{|c|c|c|}
\hline $\begin{array}{c}\text { Query } \\
\text { References }\end{array}$ & Query & Remark \\
\hline q1 & $\begin{array}{l}\text { AUTHOR: A running head short title was not } \\
\text { supplied; please check if this one is suitable and, if } \\
\text { not, please supply a short title that can be used } \\
\text { instead. }\end{array}$ & \\
\hline q2 & $\begin{array}{l}\text { WILEY-BLACKWELL: The email has been } \\
\text { changed from M.ThiteREMOVETHISTEXT@ } \\
\text { REMOVETHISTEXTgriffith.edu.au in the } \\
\text { original manuscript; please confirm that is OK. }\end{array}$ & \\
\hline q3 & $\begin{array}{l}\text { AUTHOR: As per journal style, please reduce the } \\
\text { number of words for the abstract to a maximum of } \\
50 \text { only. }\end{array}$ & \\
\hline q4 & $\begin{array}{l}\text { AUTHOR: This Abstract has been chosen rather } \\
\text { than the following; please confirm that is OK: } \\
\text { The inherent negative characteristics of offshored } \\
\text { call centre work, with high performance } \\
\text { monitoring and low job discretion are said to } \\
\text { contribute to employee dissatisfaction. This study } \\
\text { of four large Indian call centre/BPO providers finds } \\
\text { that there is a profound mismatch between the BPO } \\
\text { labour market and the labour process that } \\
\text { characterises much of the work. This situation } \\
\text { poses fundamental challenges to the BPO model of } \\
\text { development that may not be susceptible to easy } \\
\text { HR fixes. }\end{array}$ & \\
\hline q5 & $\begin{array}{l}\text { AUTHOR: Please check if heading levels } \\
\text { throughout the text are correct. }\end{array}$ & \\
\hline q6 & AUTHOR: Please define HRM. & \\
\hline q7 & $\begin{array}{l}\text { AUTHOR: Boltanski and Chiapello, } 2007 \text { has been } \\
\text { changed to Boltanski and Chiapello, } 2005 \text { so that it } \\
\text { matches the Reference list; please confirm that it is } \\
\text { OK. }\end{array}$ & \\
\hline
\end{tabular}




\begin{tabular}{|c|c|}
\hline q8 & $\begin{array}{l}\text { AUTHOR: Gereffi and Korzeniewicz, } 1994 \text { has } \\
\text { been changed to Gereffi, } 1994 \text { (the author rather } \\
\text { than the editors) so that it matches the Reference } \\
\text { list; please confirm that it is OK. }\end{array}$ \\
\hline q9 & $\begin{array}{l}\text { AUTHOR: 'As such, common ...' This sentence } \\
\text { has been reworded for clarity. Please check and } \\
\text { confirm if it is correct. }\end{array}$ \\
\hline q10 & $\begin{array}{l}\text { AUTHOR: Slater, } 2004 \text { has not been included in } \\
\text { the Reference List, please supply full publication } \\
\text { details. }\end{array}$ \\
\hline q11 & $\begin{array}{l}\text { AUTHOR: Budhwar et al. } 2006 \text { has been changed } \\
\text { to Budhwar et al. 2006a,b throughout the text so } \\
\text { that it matches the Reference list; please confirm } \\
\text { that it is OK. }\end{array}$ \\
\hline $\mathrm{q} 12$ & $\begin{array}{l}\text { AUTHOR: Shah and Bandi, } 2003 \text { has been } \\
\text { changed to Shah and Band, } 2003 \text { so that it matches } \\
\text { the Reference list; please confirm that it is OK. }\end{array}$ \\
\hline q13 & $\begin{array}{l}\text { AUTHOR: 'In other words...' This sentence has } \\
\text { been reworded for clarity. Please check and } \\
\text { confirm if it is correct. }\end{array}$ \\
\hline q14 & $\begin{array}{l}\text { AUTHOR: 'In the following analysis...' This } \\
\text { sentence has been reworded for clarity. Please } \\
\text { check and confirm if it is correct. }\end{array}$ \\
\hline q15 & $\begin{array}{l}\text { AUTHOR: 'Minimally, it required...' This } \\
\text { sentence has been reworded for clarity. Please } \\
\text { check and confirm if it is correct. }\end{array}$ \\
\hline q16 & $\begin{array}{l}\text { AUTHOR: 'In three instances ...' This sentence } \\
\text { has been reworded for clarity. Please check and } \\
\text { confirm if it is correct. }\end{array}$ \\
\hline q17 & $\begin{array}{l}\text { AUTHOR: Taylor and Bain, } 2004 \text { has not been } \\
\text { included in the Reference List, please supply full } \\
\text { publication details. }\end{array}$ \\
\hline q18 & $\begin{array}{l}\text { AUTHOR: 'Between a fifth ...' The meaning of } \\
\text { this sentence is not clear; please rewrite or confirm } \\
\text { if it is correct }\end{array}$ \\
\hline q19 & $\begin{array}{l}\text { AUTHOR: Batt et al., } 2005 \text { has been changed to } \\
\text { Batt et al., 2005a,b. Please check if this is correct } \\
\text { and Batt et al., } 2006 \text { has not been included in the } \\
\text { Reference List, please supply full publication } \\
\text { details. }\end{array}$ \\
\hline
\end{tabular}




\begin{tabular}{|c|c|}
\hline q20 & $\begin{array}{l}\text { AUTHOR: Please check all website } \\
\text { addresses/URLS in Reference List and confirm } \\
\text { that they are correct. (Please note that it is the } \\
\text { responsibility of the author(s) to ensure that all } \\
\text { URLs given in this article are correct and useable) }\end{array}$ \\
\hline q21 & $\begin{array}{l}\text { AUTHOR: Please provide the page range in } \\
\text { Reference Batt, et al.; 2005a. }\end{array}$ \\
\hline q22 & $\begin{array}{l}\text { AUTHOR: Please provide the page range in } \\
\text { Reference Gereffi; } 1994 .\end{array}$ \\
\hline q23 & $\begin{array}{l}\text { AUTHOR: Please provide the accessed date for } \\
\text { Reference Holman, et al.; } 2007\end{array}$ \\
\hline q24 & $\begin{array}{l}\text { AUTHOR: Please provide the page range in } \\
\text { Reference Korczynski; } 2001 \text {. }\end{array}$ \\
\hline q25 & $\begin{array}{l}\text { AUTHOR: Please provide the page range in } \\
\text { Reference Mirchandani; } 2009 .\end{array}$ \\
\hline q26 & $\begin{array}{l}\text { AUTHOR: Please provide the initials of } \\
\text { Marasigan-Pasumbal in Reference Ofreneo et al.; } \\
\text { 2007. }\end{array}$ \\
\hline q27 & $\begin{array}{l}\text { AUTHOR: Please provide volume number for } \\
\text { Ramesh, } 2004 .\end{array}$ \\
\hline q28 & $\begin{array}{l}\text { AUTHOR: Please provide the page range in } \\
\text { Reference Srivastava, Theodore; } 2006 \text {. }\end{array}$ \\
\hline q29 & $\begin{array}{l}\text { AUTHOR: Please provide the page range in } \\
\text { Reference Srivastava, Theodore; } 2006 \text {. }\end{array}$ \\
\hline q30 & $\begin{array}{l}\text { AUTHOR: Please provide the page range in } \\
\text { Reference Thite; } 2008 \text {. }\end{array}$ \\
\hline q31 & $\begin{array}{l}\text { AUTHOR: Please provide the page range in } \\
\text { Reference Thite, Russell; } 2007 .\end{array}$ \\
\hline q32 & $\begin{array}{l}\text { AUTHOR: Please check if column heading is } \\
\text { correct. }\end{array}$ \\
\hline q33 & $\begin{array}{l}\text { AUTHOR: Please check if column heading is } \\
\text { correct. }\end{array}$ \\
\hline
\end{tabular}

